\title{
ICTs and Child Labour in Nigeria: Patterns, Implications and Prevention Strategies
}

\author{
Jimoh Femi Olatunji ${ }^{1}$, Amah Nnachi Lofty ${ }^{2}$, Dr. Oyedemi Jacob ${ }^{3}$ \\ ${ }^{1}$ Department of Physical and Health Education, Federal College of Education, P.M.B 39, Kontagora, Nigeria \\ ${ }^{2,3}$ Department of Computer Science, School of Sciences, Federal College of Education, P.M.B 39, Kontagora, Nigeria
}

\begin{abstract}
There are many children in Nigeria who work under inhuman conditions hidden from public view and recognizing that ICT has the capacity to make children visible and countable, consequently making adults and government accountable for their welfare and protection. This paper analyse the patterns and implications of child labour and seek to find preventive strategies that could quash these deep seated social and humanitarian conundrums in Nigeria. It enlivens our consciousness that mobile technologies play important roles in children lives who are residents in the digital era and could proactively operate and share information on rights and privileges, and to the reality of receiving guidance and protection from secular authority against abuse and forced labour. The paper concludes that child labour is a crime against humanity and should be condemned by all.
\end{abstract}

Keywords: Child labour, ICT, poverty, prevention, education, hunger

\section{Introduction}

Child labour violates the principles as contained in two international treaties which Nigeria is signatory namely; the 1987 United Nations Convention on the Rights of the Child and the 1991 Africa Union Charter/on the Rights and Welfare of the Child. While child labour is not recent phenomena, it is a festinating scourge afflicting countries and retarding development with millions of children deprived of their childhood, and are condemned to a life of poverty and want (UNCRC, 1989).

Undoubtedly, throughout ages and in all cultures children joined their parents to work in the fields, in the market place, and around the homes as soon as they were old enough to perform simple tasks. Such engagements when bears no risk to the child's safety and educational training, physical and mental growth, however count as economic activity. Of course, these are works that children do to help their families in ways that are neither harmful nor exploitative. The use of child labour was not regarded a social problem until the introduction of the factory system which (Farr and Kaufman, 2009) refers to as a large establishment employing many people who are involved in mass production of industrial and consumer goods.

Globally, it is estimated that 168 million children aged 5 to 17 are subjected in child labour and over 120 million among them falls below the age of 14 , while above 30 million children in this age group mostly girls perform unpaid household chores within their own families and in its modern trend, including slavery like practices of bonded labour, child soldiering, sexual exploitation and drug trafficking (UNICEF, 2015). To some of these children the main obstacles to education are not school availability, cost or quality, but rather poverty, economic insecurity, discrimination and cultural practices.

Similarly, there are many children in Nigeria who work under inhumane conditions hidden from the public view. The conditions of some of these children are compounded by the fact that they do not receive any kind of formal education. The "free education" available in many local and state governments across the country does not provide the desirable tools for future freedom from ignorance or even preparation for work after education. Lack of health care and missing out on education makes it impossible to break the cycle of poverty and exploitation and prevents them from having a better life and a safer future (Thisday, 2015). Thus, child labour remains a major concern in Nigeria as evident with the sight of street hawkers, beggars, car cleaners, apprentice, betrothal and child marriage, and almajiri in the northern part of the country.

Child labour is preventable, not inevitable and there is a bond agreement that information and communication technology is in the midst of wave of innovations characterized by the confluence of social, mobile and cloud technologies in a cosumerized knowledge society towards human resource development. Notably, internet and mobile technologies are increasingly becoming indices for children growth, who are dependent on these technologies to learn, engage, play, work and socialize anytime and anywhere.

Consequently, this paper analyse the trends and seek to find preventive strategies against child labour, and solutions that could quash these deep seated social and humanitarian conundrums. It considers ICT as a bedrock for the survival and development of Nigeria in a rapidly conglomeration of global space with benefits to poverty reduction, quality education, improved health, skilled human resources and child protective measures in a socially inclusive generation.

\section{Context of Child Labour}

Experts in the study of society have described child labour as the employment of children in any work that deprived children of their childhood, interferes with their ability to attend regular school, hence is mentally, physically, socially or morally dangerous and harmful. However, article 1 of the 1987 United Nations Convention on the Rights of the Child 


\section{International Journal of Science and Research (IJSR) \\ ISSN (Online): 2319-7064}

Index Copernicus Value (2013): 6.14 | Impact Factor (2015): 6.391

defines a child as anyone under the age of 18 (UNCRC, 1989).

According to UNICEF (2002) child labour refers to children working in contravention of ILO standards in convention 138 and 182 , that is, all children below 12 years working in any economic activities, those aged 12 to 14 engaged in more than light work, and all children engaged in the worst forms of child labour. Worst forms of child labour refers to children being enslaved, forcibly recruited, prostituted, trafficked, force into illegal activities and exposed to hazardous work. From the foregoing, the authors defines Child Labour as;

"The subjection of children under the age of 18 to any work or forceful act that deprive them of childhood right to education, health care, and overall physical and mental development of the child"

The Nigerian child has been forced into different forms of labour in different parts of the country resulting to erosion of principles that characterized the right of a child.

\section{ICT and Child Labour in Nigeria}

Information and Communication Technology according to UNChronicle (2011) is deeply woven into the fabrics of society and is integral way we engage in everyday activity. ICT is an umbrella term that includes any communication device or application, encompassing: radio, television, cellular phones, computer and network hardware and software, satellite systems and so on, as well as the various services and applications associated with them, such as videoconferencing and distance learning. ICTs are often spoken of in a particular context, such as ICTs in education, health care and social welfare (TechTarget, 2005).

Despite the Child's Rights Act (CRA) enacted by the Nigeria National Assembly on 31st July, 2003, cases of child right violation still persist (Taiwo, 2013). Only 26 out of 36 states in Nigeria, as at May 2014, have signed the act into law and have domesticated the provisions therein. While others, mostly the northern states are at disputes with the minimum age of the child due to culture, religion and custom of various tribes owing to the multi ethnicity of the nation.

According to 2014 Global Survey Index, Nigeria ranked $6^{\text {th }}$ of ten countries with highest number of people in modern slavery and labour. These ten countries account for $71 \%$ of the total estimate of 35.8 million people living in modern slavery (GSI, 2014). Conflict and violence have contributed to high rate of child labour in Nigeria with prevalent chronic insecurity and displacement of indigenous habitat where over 71 percent lives on less than one dollar a day, while 92 percent lives on less than two dollars a day (Regha \& Amah, 2015). An estimated 2.7 million people according to UNOCHA (2016) of whom 1.5 are children having been displaced by violence perpetrated by Boko Haram in the North East of the country and boys forcibly enrolled as combatants, with its antecedent breakage of family bonds and social structure. A disaster that have caused people living in an overcrowded internally displaced camps.
The National Agency for Prohibition of traffic in Person and other Related Matters, in 2012 described Abakaliki area of Ebonyi State as a factory where children that labour at rice mills and quarries are produced in large quantity (Nigeriavillagesquare, 2012). The danger of children in any quarrying supply chain are clear; from associated health hazards, very low life expectancy to dehumanization and exploitative employment. However, the often perceived that household poverty is the main proponents of child labour and out of school resurgence may have been exaggerated. It is rather that their exclusion is simply one more manifestation of a web of rights violation. Hence, the fear to fall deep into poverty and low family esteem may be even more important to whether a child stays in school or has to play a different role in the household risk mitigation strategy.

Of great concern is the Almajiri syndrome in the northern Nigeria, which seem to be encouraged by the political elite and industrialist who scout for cheap labour, and who has found mass political and social followership among uninformed youth in an acculturated religiously tensed environment. Promising as it may, the Free Feeding Programme at primary schools by the Kaduna State government in January 2016, increased pupils attendance enrollment into basic education by $64 \%$ across the state. Reports indicates that Secondary school enrolment which stood at 243,000 in the 2014/2015 academic session increased to over 446,000 . In the primary schools, the enrollment which was 1.1 million in 2014/2015 academic session, now stands at about 1.8 million (Leadership, 2016). An indication that poverty and hunger remains a major factor to low access to education by children who find solace in social labour to fend for themselves even after the one meal gesture. Typically, cultural norms and expectations in many places explains more of labour and schooling choice. The reasons hinge on the premise that in a milieu of cultural norms and expectations, the interactions may become obstacles to social inclusion and education of vulnerable children.

In Nigeria, the use of Facebook, WhatsApp, Twitter, Short Message Services and other social-technological media is exceedingly popular among children. Amah et al (2015) posited that Nigeria is now one of the fastest growing smartphone destination globally, having the highest number of mobile subscriptions in sub-Sahara Africa. Mobile technologies play important roles in children who are residents in the digital era and could proactively operate and share information on rights and privileges, and to the reality of receiving guidance and protection from secular authority against abuse and forced labour.

\section{Causes of Child Labour}

Ojo (2004) reported that a number of factors are responsible for child labour. These factors include; poverty, large family seize, family tradition, socialization process, poor scholastic achievement, home conditions, rural-urban migration and high demand among employers for cheap and submissive child labour especially in the informal sectors. Gerry and Eze (20012) citing several authors concluded by reporting the following as causes of child labour; poverty, lack of educational opportunities, parent's choice, need to contribute 


\section{International Journal of Science and Research (IJSR) \\ ISSN (Online): 2319-7064}

Index Copernicus Value (2013): 6.14 | Impact Factor (2015): 6.391

towards basic household income. need for extra extra money, derivation of satisfaction from work, compelled to work by adults to pay bills, death of parents, collapse of family or rejections by family. Other reasons are; sick or bed-ridden parents, psychologically-imbalanced parents or guidance, breakdown in extended family affiliations, high school dropout rates and ack of enforcement of legal instruments meant to protect children, and so on.

Traditionally, children have worked with families, but today children are forced to work for their own and their family's survival. The money earned by child family members has become a significant part of poor families' income. These children who work suffer from fatigue, irregular attendance at school, lack of comprehension and motivation, improper socialization, exposure to risk of sexual abuse, high likelihood of being involved in crime (UNICEF, 2007).

\section{Forms of Child Labour}

In its most extreme forms, child labour involves children being enslaved, separated from their families, exposed to serious hazards and illnesses or left to fend for themselves on the streets of large cities, often at a very early age. Whether or not particular forms of "work" can be called "child labour" depends on the child's age, the type and hours of work performed, the conditions under which it is performed and the objectives pursued by individual countries. Ojo (2004) reported the following as forms of child labour;

1. Factory/industrial child labour: This type of child labour is carried out by the private sectors of the economy where under age children are recruited and exploited.

2. The child in the family labour: This practice is as old as Nigeria society itself. This is the situation whereby children are seen helping in the farms, house, markets, shops or workshops. Children fetch water, firewood for domestic uses, hawk wares and petty food items on the streets and in markets places.

3. Maid/Domestic child servant: Children are employed as domestic servants or house-helps in Nigeria societies. It is a practice common among the elite.

4. Apprentice child labour:- The apprentice is a child learning a trade under a caretaker, away from the parents. He may not be paid until he has fully learned the trade for about three years or more.

5. Alien child labour: These includes destitute, refugees and middle men from neighboring countries to another country to work as domestic labour.

6. Commercial sexual exploitation of children (CSEC): According to Platt (2002), every day, boys and girls and transgender youths are being sexually exploited world wide, not only by foreigners, but also by locals, not only by men, but also by women. Sexual exploitation is one of the most serious forms of gender-based violence and child labour, affecting children worldwide. The three common forms of sexual exploitation are; Prostitution, pornography and trafficking for sexual purposes.

\section{Patterns of Child Labour in Nigeria}

In Sub Saharan Africa, complex patterns of migration, fueled by lack of economic opportunity, conflicts and climate related disorder force millions of migrants to travel from rural areas to cities as refugees, stateless and as economic migrants. Migrants are vulnerable to exploitation in the Sub Saharan region and as foreign workers in the informal sectors overseas in Europe and the Gulf. The 2014 Global Survey Index indicated that migrants' laborers lack the protection of labour laws and are unable to access social services and are often subjected to mythical bond of allegiance and their precarious visa status dissuade them from reporting to authorities (GSI, 2014).

Moronkola and Okanlawon, (2003) citing Isamah (1997), Bassey, Baghebo and Otu, (2012) reported the pattern of child labour in Nigeria by zones as indicated in the table:

Table 1: Patterns of child labour in Nigeria

\begin{tabular}{|c|c|c|c|c|}
\hline South West & South East & North West & North East & $\begin{array}{l}\text { North } \\
\text { Central }\end{array}$ \\
\hline $\begin{array}{l}\text { Street trading, } \\
\text { apprenticeship, } \\
\text { domestic } \\
\text { services, hotel } \\
\text { attendant, } \\
\text { vending, car } \\
\text { washing, } \\
\text { hawking, } \\
\text { vulcaniser, bus } \\
\text { conducting, } \\
\text { prostitution, } \\
\text { potage, } \\
\text { weaving and } \\
\text { factory work, } \\
\text { erating, } \\
\text { begging, shoe } \\
\text { shinning }\end{array}$ & $\begin{array}{l}\text { Street trading, } \\
\text { apprenticeship, } \\
\text { domestic } \\
\text { services, } \\
\text { vending, car } \\
\text { washing, } \\
\text { hawking, } \\
\text { vulcaniser, bus } \\
\text { conducting, } \\
\text { prostitution, } \\
\text { and factory } \\
\text { work }\end{array}$ & \begin{tabular}{|} 
Street \\
trading, \\
herding, \\
farming, \\
shoe \\
shining, \\
begging, \\
garage \\
boys, \\
erating, \\
hawking, \\
vulcanizer, \\
and factory \\
work
\end{tabular} & \begin{tabular}{|} 
Street \\
trading, \\
herding, \\
farming, \\
kiosk \\
operation, \\
shoe \\
shining, \\
begging, \\
garage \\
boys, \\
erating, \\
hawking,
\end{tabular} & $\begin{array}{c}\text { Street } \\
\text { trading, } \\
\text { herding, } \\
\text { kiosk } \\
\text { operation, } \\
\text { begging, } \\
\text { nail } \\
\text { cutting }\end{array}$ \\
\hline
\end{tabular}

It is disturbing that in the $21^{\text {st }}$ century, especially in subSaharan Africa, and the third world nations, child labour situation seems, to have been in the increase despite reported measures.

\section{Circumstances that Give Rise to Child Labour in Nigeria}

Child labour remains a major source of concern in Nigerian in spite of legislative measures taken by the government of various levels. In 1998, the international labour organization (ILO) estimated that 24.6 percent of children between the age 10-14 in Nigeria were working. Earlier before that time in 1994, the United Nation Children Emergency Fund (UNICEF) reported that approximately 24 percent (12 million) of all children under the age of 15 worked (UNICEF, 1995). It is ridiculous sight in most big cities, as well as rural villages today, to see children of school age, trading food on the streets, herding animals, tanning and drying raw leather products fetching water for commercial purposes, washing dishes at restaurants, serving as domestic hands, selling wares at kiosks, collecting firewood for business, harvesting crops in family farms or commercial plantations, amongst other activities (Ajah, 1990)

There are different types of children whose circumstances of both and environment they live tend to make them different from other children. According to Moronkola and 


\section{International Journal of Science and Research (IJSR) \\ ISSN (Online): 2319-7064}

Index Copernicus Value (2013): 6.14 | Impact Factor (2015): 6.391

Okanlawon (2003), summarized the options of other experts and categorized these children as;

i. Working children: Work sustains a society's developmental efforts and work in one form or another prepares children for greater opportunities later in life. However, there must be a demarcation of what constitutes "normal" and "abnormal" work for children. In most societies, most types of child-work take place mostly within the family context and is largely regarded as desirable and socially approved. Accurate data on child abuse or maltreatment are difficult to come by in Nigeria. However, it is estimated that millions of Nigerian children who are below 15 years will be working. Poverty, broken homes delinquency, illiteracy and family size are some of the causes forcing children to start work too early in Nigeria.

ii. Street children: There are millions of children in the world who look for their survival on the streets of cities. Street children either live, work or to both together on the street either with regular or irregular visits to homes or total loss of contact with homes. Their living on the street poses a great danger to their health and that of the general society. Many experts believed that street life makes the girls to be sexually exploited while boys could be easily recruited as thugs or be victims of ritual killings.

iii. Children from Broken Homes: There are indications to suggest that marital separations lead to increased risk of ill-health to children and low income and per-capital consumptions where there is marital disruptions resulting to women leading house-holds. A child from broken homes, suffers from physical, spiritual and psychological problems

iv. Victims of Early Marriage: The UN convention on the rights of the child believe dearly/child marriage is one between human beings below the age of eighteen (18) years. Early marriage is one of the harmful traditional practices in Nigeria today which has caused untold hardship on the health of the new born and the child's mother. Teen marriage may lead to school dropout, high level of illiteracy, socio-emotional problems and large family size.

v. Abuse and neglected children: A child may be abused physically through excessive beatings, capital punishment like severing body parts as punishments against stealing or perceived witchcrafts. A child may also be sexually abused. Abandoned children, unwanted or neglected children usually suffers psychological deprivations in life. Children like adults have rights to be respected and protected and when such rights are derived them or they are not protected then they can be said to be abused and neglected.

vi. Children of the insane, prostitutes and destitute: Children of the insane and destitute are usually in precarious states as their parents (mostly mothers) are not in good mental states to care for them. They lack all the necessary essentials of life, good shelter, food, and clothing and are exposed to varying weather conditions. They are denied educations and do not have the opportunity to play and learn from other children as their mothers always guard them jealously.

vii. Victims of civil and religious disturbances: The effects of violence and war resulting from civil and religious disturbances are usually felt more by the mothers and children. Many of them turn to sexual exploitations even in refugee camps. Each child is unique and the needs of children in difficult circumstances, needing special protections measures and so on can only be met in a conflict free working environment and environment free of child's exploitations.

\section{Implications of Childs Labour}

a. School/Academic implications: Gerry and Eze (2012) reported the following as school/academic achievements implications of child's labour;

- Lack of spare time to go to school or handle school assigned tasks.

- Retardation of child's intellectual development

- Drop-out from school

- Inability to learn or disinterest at school

- Inability to build or maintain interpersonal relationship with peers and teachers.

b. Medical/Health implications: According to Mohan (2005), a child is any person under the age of eighteen years. This of course is the age brackets for most persons in primary and secondary schools. Thus, individuals or societies inter-posing the lives of these children at this formative age, expose them to very grave health consequences, since their tender anatomy and physiology are not equipped to handle these challenges. Child prostitutions exposes these young stars to various sexually transmitted diseases (STD's) such as gonorrhea, candidiasis, chlamydia vaginoses, genital herpes, HIV-AIDs, and cancer of the interline cervix, for the girl child (Freudenberg, 2005). Begging, peddling of wares and non-domestic or paid works exposed the child to the hazardous effects of the ultra violet rays of the sun. Prolong expose to sun light predispose one to cancers of the skin. The individuals most susceptible to these cancers are light skinned individuals and albinos (Attah, 2000). The health implications of wage labour include: occupational hazards such as industrial accidents, chronic obstructive pulmonary diseases (COPD) such as asthma, chronic bronchitis, bronchiectasis and emphysema; pneumoconiosis and cancers of the airway (Husain and Kumar, 2005). All these are necrotizing and allergic conditions of the airway caused by particulate matter, smoke and toxic substances that are generated in factories the end result of COPD and pneumoconiosis is pulmonary hypertension and right heart failure.

c. Physical implications of child labour: These include; low payments for child labour, physical molestation at work place, exposure to extreme heat or cold, lack of spare time to play with peer groups, exclusion from social activities, sexual and physical abuse, exploitation of children especially those children who share their income with their family (Hussain and Kumar, 2005).

d. Social implications of child labour: The social implicationsof child labour are manifold for the development of any nation especially Nigeria. According to Olagbegi (2004), the subjection of children to slave-like labour, some of which are the worst form of labour, seriously impaired the youth and development of Nigerian children who are the bed rock of the society. Children laborers are derived education, basic standard 


\section{International Journal of Science and Research (IJSR) \\ ISSN (Online): 2319-7064}

Index Copernicus Value (2013): 6.14 | Impact Factor (2015): 6.391

of living and fundamental human rights, dignity and freedom. All these makes the child less important, depressed and rejected by the society.

e. Other implications of child labour on child's mental health includes: these includes; retardations of the child's physiological development, emotional problems, malnutrition, unwanted pregnancy, addiction to bad habits (drinking alcohol, smoking cigarette e.t.c.), early exposure to sex predispose their to HIV/AIDs, maladjustment due to harsh treatment from labour masters, aggressive personalities due to unfair treatments, anxiety and lack of confidence in approaching problems especially when physical and psychologically abused, frustration, low self-esteem and health problems (Gerry and Eze, 2012).

\section{Sectorial Distribution of Child Labour}

Child labour distribution by branch of economic activity as represented by International Labour organization is shown in fig 1.



Figure 1: (Source: ILO; Marking Progress against Child Labour, 2013).

The chart conforms with Federal Ministry of Labour and Productivity report of the sectoral/industrial distribution of child labour in Nigeria which is summarized thus;

1. Agriculture: The activities grouped includes production of manioc/cassava, cocoa, tobacco, Herding livestock, fishing and so on.

2. Industry: Mining and quarrying granite and gravel and breaking of granite into gravel, harvesting, artisanal gold mining and processing.

3. Services: they includes auto repairs, domestic services, street hawking, conducting minibuses, street begging including by Almajiri

4. Categorical worst forms of child labour: This includes commercial sexual exploitation, street hawking, mining and quarrying gavel and granite, and work in agriculture, including in cocoa, as a result of human trafficking; used in armed conflicts sometimes as a result of forced recruitment, including as messengers, transporters, informants, spies and suicide bombers.

\section{Policy Measures towards Curbing Child Labour}

- Awareness should be conducted through raising programme for children as well as employers, parents and decision makers regarding the harmful effects of child labour

- Awareness of the risks of HIV/AIDs should be spread at all levels, which is vital weapon to discourage child prostitution.

- $\quad$ The federal government should try as much as possible to reduce poverty in the country

- Parents should treat their children in a proper manner and proper family planning be considered.

- Social security services like registration of the employed and aged persons and monthly payments should be made to the affected citizens to help in meeting their basic needs.

- Professional guidance and counsellers and other trained media professionals can help sanitize parents and guidance concerning child right and effect of child labour. This could be through schools, churches, community groups and media.

- Training about child rights should be given to law enforcers; judges; police and so on to protect the victim and punish the perpetrators

- Practicing school counselors should be made to work alongside the classroom teachers to help them identify at-risk and active child labourers whose conditions is affecting their academic performance.

- Government should adopt legislature measures strictly prohibiting employing children under 18 years of age in child's prostitutions which is another worst form of child labour.

- Government should inculcate the need of the child in the education policy in a way that the teaching of children's right will be injected.

- Moreso counselling workshops be organized in schools and outside the school in other to help reach out to the victim's family.

\section{ICTs Innovative Strategies Against Child Labour}

Mobile and digital technologies are becoming increasingly important for international development and humanitarian agenda, and is one of the fastest growing sectors in Africa as reflected in the trends in mobile subscriptions in Africa between $2015-2015$. 


\section{International Journal of Science and Research (IJSR) \\ ISSN (Online): 2319-7064}

Index Copernicus Value (2013): 6.14 | Impact Factor (2015): 6.391

Trends in mobile subscriptions in Africa 2005 - 2015

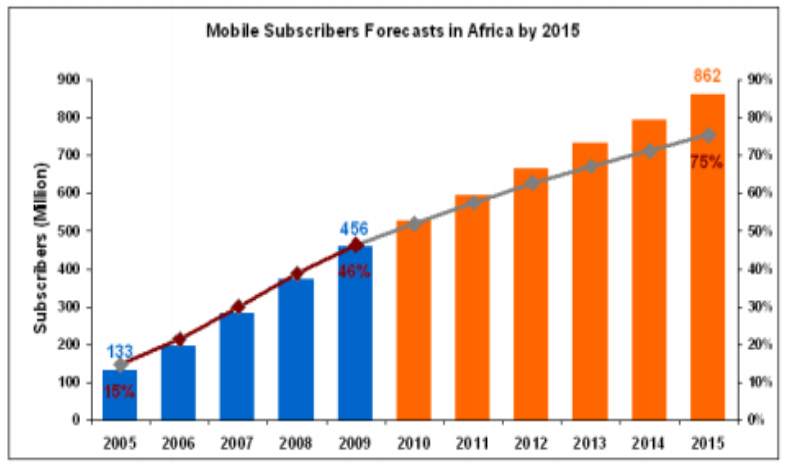

Figure 2: (Source: UNICEF, 2015)

The proposal for relevant technologies and mobile applications for child protection as identified by Mirkka (2011) among others include the following;

1. Birth \& Death Registration System: First and foremost, birth registration provides a child with legal right to social services, health, education and protection against dehumanization. It is quite worrisome that the birth of nearly 230 million children under the age of 5 worldwide, about one in three have never been officially recorded depriving them of their right to a name and nationality (UNICEF, 2015). Having birth registration centers in rural and urban areas in collaboration with traditional and local authorities, with smart applications where data are collected at local level are entered into digital forms on a smartphone and are then transmitted to the civil registrar office who issues the birth certificate while the data are sent to a central birth registration database. It ensures data accuracy and security, checking, speed and quick access to data among parents and state authorities for onward child protection measures. A case of the Uganda Mobile Vital Record System (MobileVRS) allows data to be transmitted by mobile device from the community and by a web based application from hospitals and then uploaded in real time directly onto the government central server. In event of demise, the record is reflected and no notification of death sent to the central server.

2. Child Protection Service Provider: This type of system identify and monitor vunerable children in order to register them with the civil registration systems. For example, the RapidSMS has the potential to collect information and provide regular data on daily basis, and can be used for family tracing and reunification of displaced persons during emergency. More importantly in countries where absenteeism is related to child labour, drop out and attendance rates of children and teachers could be monitored with Short Service Message. The service platform enables collaboration between agencies and children in need of care and protection in times of crisis when families may get separated and dispersed. The system helps aid workers to collate and register children in their care, and search existing entries to help parents and other relatives find missing children.

3. Extreme poverty: Described as primary cause of child labour with $58.6 \%$ found in the agricultural sector, but
ICT can provide powerful tools in the fight against extreme poverty and in emergency situations where there is problem of ensuring the right help reaches the right people who are in need. Strategically, ICT can be used to inform, trace and monitor supply chains to improve accountability. ICT has the capacity to generate employment at a reasonable level of productivity and its growing share in incremental GDP.

E-business, e-commerce and mobile financial services increase social and financial inclusion of the poor. ICT is a trigger for increasing productivity and competitiveness among Small and Medium Enterprises (SMEs) and for digital entrepreneurship. ICT increases literacy and engagement of people living in poverty and develops vocational skills for the future.

4. Optimizing Agriculture: Sub-Saharan Africa's economic backbone Use of mobile solutions is helping farmers in Africa to minimize economic risk by knowing when to plant their crops, as well as reduce the time it takes to get crops to the market. Considering that agriculture employs more than half of Sub-Saharan Africa's workforce and accounts for a third of its GDP, mobile-based solutions will go a long way towards improving the socio-economic environment in the region. The use of Geospartial System if depolyed effectively in the Nigeria case would provide farmers information on soil condition, best suitable crops for the soil, pest and disease control, climatic condition and food security measures

5. Mobile Cash Transfer: Cash transfer by text message is a flexible and convenient means of transmitting information and money, contributing to poverty reduction and social protection, and bridging the movement of goods and services between the rural and urban space. The mobile fund transfer is simple to use and connects the banks and the unbanked people through better and immediate access to cash without a bank account.

6. Quality of Education: Simply giving children access to technology is not enough, there will be need for guidance to help them over time to maximize the benefits to improve learning outcome of children. ICT can play different roles in facilitating both formal and non-formal education, and promotes indigenous language through bespoke and easy to use selfeducational instructional media for children. ICT offers mobile collaborative learning tools among young learners and teachers, engaging on topics, solving problems using language that they understand.

According to Amah et al (2015) mobile collaborative learning offered the possibility to conduct democratic learning in a much instant texting, file sharing, voice and video interactions, and to prepare a future generation of learners, it is imperative to implement this pedagogical approach of learning in daily teaching practice.

7. Good Governance and Accountability: ICT has the capacity to make children visible and countable, consequently making adults and government accountable for their welfare. This is an important component in the process of strengthening the social 


\section{International Journal of Science and Research (IJSR) \\ ISSN (Online): 2319-7064}

Index Copernicus Value (2013): 6.14 | Impact Factor (2015): 6.391

contract between government and citizens. Creating technology based unique IDs during birth via mobiles in rural areas secures child's right and entitlements, and making information and advice more available and creating child helplines to respond appropriately when the need arises. However, accountability and good governance will depend on the quality of institution, policy and implementation systems to deliver better results for children (Dorothea, David and Sannia,2013).

\section{Conclusion}

Child labour is a crime against humanity and it should be condemned outrightly. No nation especially a developing nation like Nigeria can move forward and deliver the dividends of democracy when she fails to recognize the plight of children in our society who are the leaders of tomorrow by empowering and encouraging the citizens towards understanding, rehabilitating and assisting the victims of child labour and melting out appropriate punishment to defaulters of laws guiding and protecting the rights and dignity of the Nigerian child.

Deploying ICTs tools to secure information about children, developing applications to monitor and support recovery for children who have been exposed to violence, abuse and exploitation. In the rural areas, there is need for government to financially support network coverage and reduction in the tax burden, import tariff on operators. Raising awareness and incentivizing the corporate sector to introduce technological related measures to enhance child's protection against all forms of forced labour.

\section{Recommendations}

- Free education should be made available to all children in the country and an enforcement of the universal basic rights to education by all children should be vigorously pursued.

- Federal government and states should develop effective ICT policy mechanisms to curtail the menace of child labour.

- Government should improve the quality of education to ensure that even children from poor homes have access to quality education.

- Specific interventions in the area of social security will still be required to minimize child labour.

- All forms of child labour expose children to exploitation and abuse. The children are force to surrender their innocence and, in many cases, their future. It is therefore important to save these children by intensifying efforts to control all forms of child labour in the country. If the youths of a country are truly the future of that country, then Nigeria's future needs a major rescue operation.

- Training law enforcement officials, teachers, child protections agencies, providing counseling and complaints platform against child labour

\section{References}

[1] Ajah, A.R. (1990). Child labour in Africa. Ibadan; University Press Ltd.
[2] Amah, N. L., Oyefeso, O. \& Ibiam, U.A (2015), Mobile Collaboration Learning Technique on Students in Developing Nations. World Academy of Science and Engineering (WASET), Dubai. International Science Index, 17,2015. Online: http://internationalscienceindex .org/publications/10002606/mobile-collaborationlearning-technique-on-students-in-developing-nations

[3] Attah, E.B. (2000). Skin; Tumours. Human Pathology. A Complete Text for Africa. Ibadan, University of Ibadan, Nigeria; 18;266-270.

[4] Bassey, E.N; Baghebo, M. \& Otu, C.A. (2012). Child labour in Nigeria and its economics implications: A case study of Calabar Municipality. Research on humanities and social sciences ISSN 2222-1719 (papers) ISSN 2222-2863 (online) vol2, nop9; 2012. Crum, C.P (2005).CERVIX. intraepithelial and onvasive squamous noeplasis. PATHOLOGIC BASIS OF DISEASE. $7^{\text {th }}$ Edition Elseviar Sacinders philadcphia, penny slavia; 1074-1079.

[5] Dorothea, K; David, H. and Sammia, P. (2013). Children, ICT and Development Capturing the potential, meeting the challenges. ISBN: 978-88-6522026-9 Innocenti Piazza Santissima Annunziata, 12 50122 Florence, Italy.

[6] Farr, G.N and kaufman, J.J (2009). Factory system".Microsoft Encanta (R). in redmond, W.A.Microsoft corporation inc.

[7] Freudenberg N, Daniels J; Crum M; Perkins T; Richie B.(2005). Coming Home from Jail: The Social and Health Consequences of Community Reentry for Women, Male Adolescents, and their Families and Communities. Am J Public Health. Vol.95(10):17251736

[8] Gerry, I.U and Eze, G.I (2012). Counselling Against Child Labour in a Developing Nation; Implications Formental Health and Academic Achievement. Journal of Educational Research and Development Ahmadu Bello University, Zaria. Vol7 NO2 Pg 159 - 163

[9] Government of Nigeria Federal Ministry of Labour and Productivity (2015). Web Page Cited June 22015. http://www/nelexnigeria.com/federal ministry-Labourand Productivity

[10] GSI (2014). Global Slavery Index. Pg 50

[11] Hussain, A.N and Kumar, V. (2005). The Lung: Obstructive Pulmonary Disease. Robins Pathologic Basic Diseases. $7^{\text {th }}$ Edition. Elsevier Sandes. Philadelphia, pennyslavis 15:717-770

[12] ILO (2007). Patterns of Child Labour in Nigeria Fact sheet. Abuja, Nigeria

[13] Leadership (2016). 2016 Budget: 17 Northern Govs To Spend Over N300bn On Education. 10 ${ }^{\text {th }}$ Janauary. Online: http://www.leadership.ng/news/490327/2016budget-17-northern-govs-spend-n300bn-education

[14] Mohan, H. (2005). Diseases of Children. Text Books of Pathology. New delthic, Jaypee Brothers Medical Publishers 110: 263-273.

[15] Moronkola, O.A and Okanlawon, F.A (2003). Fundamental of Public and Community Health Education. Royal People (Nigeria) Ltd. Ibadan.

[16] NigeriaVillageSquare (2012). 75\% of Kid Hawkers, Slaves from Ebonyi. Online: 


\section{International Journal of Science and Research (IJSR) \\ ISSN (Online): 2319-7064}

Index Copernicus Value (2013): 6.14 | Impact Factor (2015): 6.391

http://nigeriavillagesquare.com/forum/archive/index.ph p/t-72817.html

[17] Ojo, R.A (2004). Child Labour and Child Trafficking in Ogundele, BO (editor) Problems in Health Education. Codat Publications Ibadan.

[18] Olagbegi, B. (2004) Trafficking of Children in Nigeria. A Situation Report "A Paper Presented at WOCONS National Workshop on Trafficking in Woman in Nigeria. The Modern Slavery Lagos, Nigeria

[19] Platt, B. (2002). Commercial Sexual Exploitation of Children: A Global Problem. Global Action. Sexual Health Exchange, thailand royal Tropical INSTITUTE.

[20] Regha, I.O. \& Amah, N.L. (2015). A Review of Information and Communication Technologies Assisted Renewable Energies as a Sine Qua Non for Solving Nigeria Energy Crisis. International Journal of Education and Research (IJER), Australia. Vol 3(3). Online: http://www.ijern.com/journal/2 015/March2015/08.pdf

[21] Taiwo , A.A, (2003). The Child's Rights Act, 2003: Provisions, Application \& You

[22] TechTarget (2005). Information and Communication Technologies. Available: http://www.searchsio.techtarget.com/definition/ICTinformationandcommunicationtechn ology

[23] ThisDay Newspaper (2015). Child Labour; A Threat to Nigeria Future. Published on $13^{\text {th }}$ December.

[24] UNChronicle (2011). Content and Design in ICT for Global Development. Vol.XLVIII, No. 3.

[25] UNCRC (1989) United Nations Convention on the Rights of the Child

[26] UNICEF (1995) The Progress of Nigerians Children: Nigeria FEDERAL OFFICE of Statistics

[27] UNICEF (2002). Building a Protective Environment for Children. Factsheet.

[28] UNICEF (2007) Child Labour. Nesbitt.

[29] UNICEF (2015). Child Protection from Violence, Expolitation and Abuse. Available: http://www.unicef.org/prot ection/ 57929_child_labour.html

[30] UNOC̄HA (2016). UN Global Emergency Fund Releases US\$31 Million to help Vulnerable People Affected by Boko Haram-Related Violence in Lake Chad Basin Region. New York, $11^{\text {th }}$ January. 